\title{
CLIMATE CHANGE ADAPTATION: STRATEGIC VISION IN AGRICULTURE
}

\author{
Deepak Mani Pokhrel $\mathrm{PhD}^{* 1}$ and Bidya Pandey $\mathrm{MSc}(\mathrm{Ag})^{2}$
}

\begin{abstract}
Climate change, including its impacts on natural resources and physical infrastructure affecting various aspects of human life, has been distressing people increasingly especially in poor economies for their limited ability to adapt to the austerities. Nepal is expectedly much vulnerable and foreseen to have pressure on its agriculture and livelihood of agrarian communities. The country's ability to adapt to the adversities has direct implications in its strategies on agriculture sector development. Agriculture sector policies, periodic plans and relevant action plans and projects were reviewed in connection to consultatively speculated vulnerabilities and impacts of climate change to appraise the country's preparedness and strength for the adaptation. The policy statements are broad enough to cover majority of vulnerability issues. And they lack optimum research need and resource availability considerations and clear pathways towards capacitating vulnerable communities to cope with the changing situations. Deficiencies in policy matters to guide state development agents through urgent and appropriate interventions, and policy makers' indulgence in fetching external supports are indicated as distracting the country away from real developmental path.
\end{abstract}

Key words: Adaptation, agrarian-community, agriculture, climate-change, livelihood, Nepal, policy, vulnerability

\section{INTRODUCTION}

Nepal is an agriculture-based country where more than $65 \%$ of the population engages in agriculture for livelihood and agriculture shares about 33\% of its GDP at current price and $35 \%$ at 2000/01 constant price (MOAC, 2010). Scientific statements regarding changing climate of Nepal are pronouncedly focused on temperature rise @ $0.060 \mathrm{C}$ per annum. Such a rise in average temperature is variable across the country (Gautam and Pokhrel 2010), higher in the mountains and Himalaya $(0.080 \mathrm{C})$ as compared to low-lying terai $(0.04 \mathrm{oC})$. As a result, series of speculation have been reported such as days and nights becoming warmer, retreating snow lines, increased evapotranspiration and peak runoff, decreasing regular water discharge in streams and recharge of natural water stores, changing water table(s) and changing pattern of precipitation in terms of form, season, duration and amount/intensity (MOE, 2010a; Gautam and Pokhrel, 2010). Also reported are decreasing total rainy days and increasing number of drier days (evapotranspiration>precipitation) and days receiving over $100 \mathrm{~mm}$ rain (MOE, 2010a; Practical Action, 2009). Precipitation, though not much varying in total amount, is mentioned being erratic and ill timed (Gurung, 2008). Weather variability associated with rising temperature and changing pattern of precipitation is expected to have utmost adverse impacts on various components of agricultural systems. The impacts, though expected to become higher in the mountains compared to low lying terai region, are detrimental to both the regions and ultimately to agricultural production, food security and the people's economic sustenance. Moreover, both the agriculture sector performance that depended mainly on conduciveness of weather conditions, and the agrarian community that showed higher intensity of poverty in the country irrespective of the regions are foremost sufferers of any adverse situation brought about by the change (MOE, 2010b; MOE, 2010c). Crop and livestock farming in different combination forms a major way of life sustenance in the communities. In this regard, combined impacts of various parameters of changing climate on biophysical and

\footnotetext{
${ }^{1}$ Senior Horticulture Development Officer, GEED(MOAC), email: deepakmpokhrel@yahoo.com

${ }^{2}$ Senior Horticulture Development Officer, GEED(MOAC)
} 
socioeconomic factors affecting livelihood of such communities is very important. Thematic Working Group (TWG) on Agriculture and Food Security was formed in the Ministry of Agriculture and Cooperatives to support National Adaptation Plan of Action (NAPA) to Climate Change Project through identification of climate change impacts and vulnerabilities and prioritized adaptation measures (MOE, 2010a). The group worked in association with a wider reference group and a task force on disaster risk management and climate change adaptation. Experienced members in the group from diverse field of agriculture, working through transact walks and series of consultative meetings, recommended forty prioritized programs and, with integration of the programs, four projects (Annex-1). Existing policy matters and successive developments on the plan were reviewed through content analysis with an objective of visualizing to what extent the recommendations by the group have been addressed. The analysis is rather subjective and confined to study of climate change and agriculture sector related policies, the recent national periodic plan and subsequent action plans and project proposals.

\section{THE THEMATIC WORKING GROUP'S VISUALIZATION AND A PERVERSIVE PLAN OF ACTION}

Impacts of climate change on agriculture are in major multidimensional and intricately vicious as 'agriculture' is function of several biotic and abiotic factors. Such as water/energy/input supply and management, weather, land system, soil environment, forest and biodiversity, labor availability, physical infrastructure, market functions/operation, knowledge, tradition, policy matters and other socioeconomic aspects are major factors deciding agricultural system operation, which are themselves in multitude of ways influenced by climatic parameters. In other words, climate change can be visualized as affecting various components in a location specific system of agriculture through its impacts not only in biophysical but also in socioeconomic factors. Fig. 1 summarizes the outcomes of the thematic working group's consultative works. It shows that the impacts of changing climate through its various parameters on biophysical and socioeconomic factors affecting a range of components in an agricultural system have ultimate negative effects on farm productivity. Some agricultural intellectuals presume some kind of positive impacts of climate change on crop and animal production also (Gautam and Pokhrel, 2010). However, harnessing such hidden opportunities by farming communities is not possible and productive due to lack of relevant knowledge and technologies. In brief, consequences of climate change in agriculture are very complex compared to other sectors. Even then, it should not be ignored in any development effort for its association with livelihoods of grassroots, social stability and well tracked development of other sectors. Moreover, a well planned agriculture development in any location contributes to better adaptation to climate change and mitigation of GHGs emission, while that on haphazard planning worsens the situation (Pant, 2009).

Being informed of the facts, the thematic working group analyzed (in major consultatively in wider group of experts) climate change impacts in important components of the country's agricultural systems and consequences in food security. Based on the group's assessment, declining forage production in natural pasture due to poor emergence of grasses, pastoral degradation and invasive species, increasing prevalence of animal parasites and vector-borne and parasitic diseases, heat stresses especially in pig, eroding breeds of sheep and pig, transhumance system loss, changes in animal reproductive behavior especially in terms of heat-period and fertility, shortage of feed ingredient and increased production of GHGs due to animal health reasons have been major impacts and concerns of climate change in animal husbandry (TWG, 2010a; TWG, 2010b; Neopane, 2010). The group, in its reports, has foreseen outbreak of feed toxicity, nutritional diseases and poor health in farm animals resulting in higher mortality rate, increasing production costs and low productivity as consequences of the impacts thereby affecting animal herders' livelihood strategy. Likewise, major impacts speculated in crop husbandry are declining availability of water for agricultural uses, hindrance in operation of conventional 
irrigation systems and decreasing water use efficiency, increasingly degrading agricultural land, increasing depletion of land from agricultural uses, diseases and pests epidemics and increasing crop management risks. Those associated with poor availability of quality planting materials and technologies, catering changing context needs, are foreseen to affect crop production and economic sustenance of farmers adversely. Agro-ecological extension of some crops due to temperature rise and increased number of warmer days, prevalence of livestock diseases and parasites and declines in fodder and forage production are reported in high mountains. The impacts reported in middle mountains and terai are decreasing crop available soil moisture, crop failures and reduced crop productivity, and those typical to terai are climate induced disasters rendering agricultural land uncultivable (MOE, 2010a).

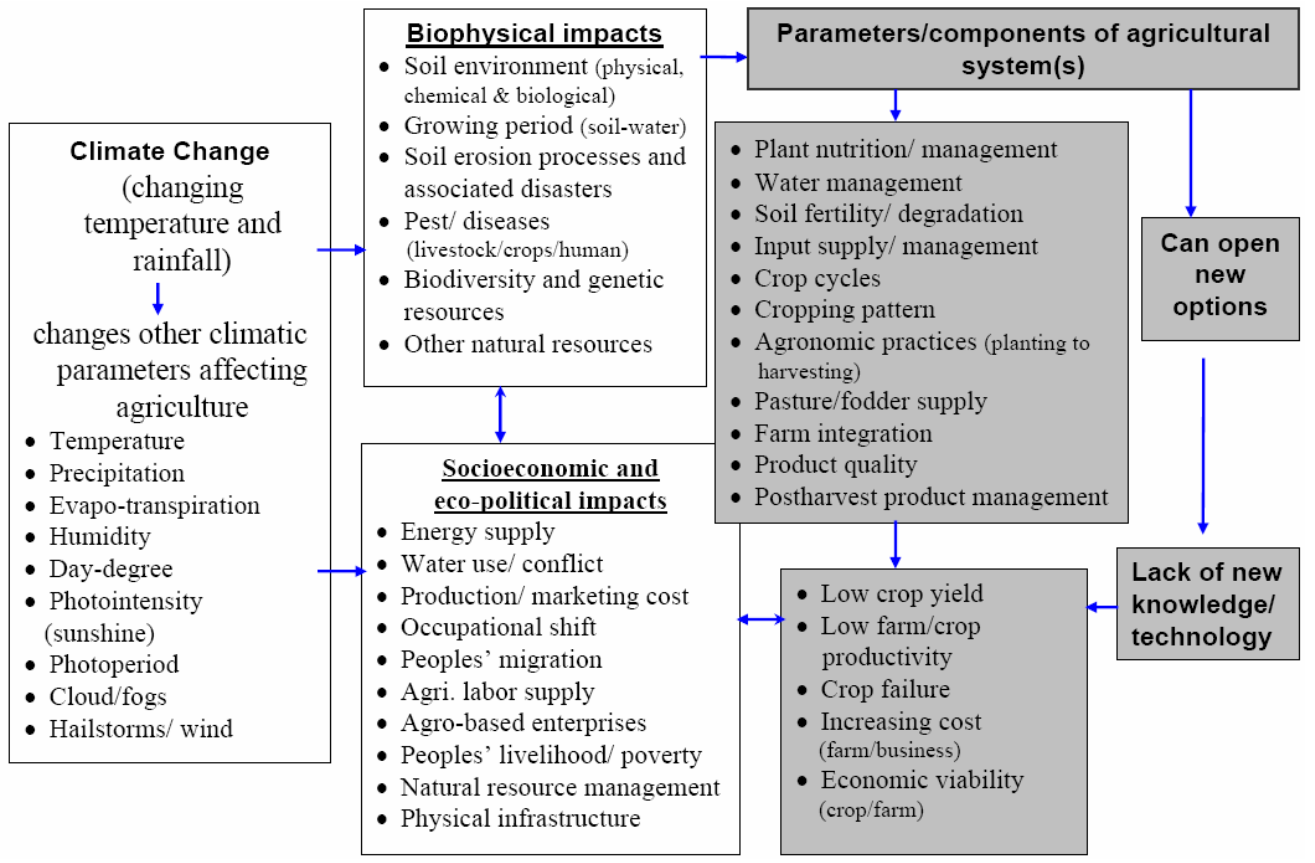

Fig.1: Speculative impacts of climate change on agriculture

The group has further explained the country's vulnerability to climate change impacts in connection to its food security (TWG, 2010b). Decreasing availability of food is presumed in the country due to decreasing crop productivity, decreasing availability of agricultural water or inefficiency of conventional irrigation systems, poor availability of quality inputs/breed, under utilization of available technologies, cereals based food habit, agricultural land depletion and degradation and, on account of those, possible occupational shifts, peoples' migration and land fallowing. Likewise, reduced access to food is anticipated because of decreasing livelihood options, imperfectness of market operation, constrained input/output distribution and increasing food import that discouraged local production. Less flexible food habit, limited food diversification, increasing cost of food quality control, increasing dependence on imported food and deteriorating traditional food market are recognized as food utilization related problems, and poor market operation and infrastructure, diseases/pests, increasing climate induced disasters and economic vulnerability as factors degrading food stability (Dahal and Khanal, 2010).

Aforesaid consequences of climate change calls for optimum management of agricultural water, soil fertility/productivity, agricultural inputs (including planting materials, crop 
varieties, animal breeds, forage and pasture), crop/livestock diseases, pests and genetic resources, food availability and access and other socioeconomic parameters such as resource use conflict, market and labor supply as major areas of interventions (MOE, 2010a; TWG, 2010b). On such ground, the group has carefully identified and recommended relevant priority programs to be integrated in any of the forthcoming climate-change management projects in the country (Annex-1), which fit to the diversity of agricultural possibilities. On top of that, the group has excavated such areas of adaptation interventions as non-conventional irrigation, rainwater harvest, on-farm resource conservation, organic agriculture, community seed bank and food buffer stock, which contribute profoundly to economic sustenance and climatic risk reduction in part of vulnerable communities as well as environmental health and resource management.

However, the story inside National Adaptation Programs of Action to Climate Change recently endorsed by the state is discouraging, which gives a general perception that the plan avoided dealing in the vicious climate change-agriculture intricacy. Instead of building on realized facts, vision, spirit and recommendation of the thematic working groups and outcomes of wider consultations (MOE, 2010b; MOE, 2010c; TWG, 2010b), the action plan has secluded, especially agricultural sector needs, inside nine-profiled jacket (MOE, 2010a). Integrating activities related to agriculture, water, forest and biodiversity in line to build community resilience is justified technically. However, looking at performance of post-NAPA projects development; it is observed that so-called integrated approach eased donors and relevant experts to abstain from agriculture related complexities. The experts' reluctance to include agrarian community's needs in the projects is visible in the post-NAPA project concept papers prepared to submit to respective donors. Such could be due to interests in part of donors to replicate implementation of adaptation models planned elsewhere or easy going motive of state bureaucrats, which is not fair to those most vulnerable in the country.

Since it is local communities, the first to be victimized due to climate change and the ones to be enabled to fight against the stringent situation, the time has come to think more on enabling the communities based on locally available means including natural, financial and human resources. Because, donors are only good wishers with preset interests; they come to meet the piloted objectives with a 'team of experts' guided well by the interests and some 'financial supports' remotely controlled. As a result, donors as guest usually tend to direct local efforts and resources mere in achieving the piloted interests. This may be the reason, why donor availed financial support is spent in high level capacity building through workshops, meetings, tours, observation-visits and formulation of manuals, frameworks, guidelines, strategies, policies, acts and regulations with very little to go to vulnerable communities and real project implementers, which can hardly be relied as contributing to grassroots' well being. Therefore, dazzling external supports should not distract strength of national development agents away from locally set visions and paths. And state policy matters should make its development agents aware of its goal, vision, mission and pathways and guide them through appropriate interventions. Likewise, implementation of the group recommended adaptation measures (Annex-1) demands for generation of location/problem specific knowledge and technology, effective dissemination of such knowledge and technologies, agriculture based early warning of weather and climate risk management, which are relevant issues to be incorporated in the state agriculture development policy and programs.

\section{POLICY AND STRATEGIES IN LINE TO COPE WITH THE IMPACTS}

Recently National Agriculture Policy 2004 is in place to guide agriculture sector development in the country. The document, in its preamble, explicates that depleting/degrading agricultural land, poor access of people (having labor force and skill) to agricultural land, limited commercial use of available land through modern technologies 
and inadequate investment on agricultural technologies and infrastructure have been root problems of slacking agricultural development in the country (MOAC, 2008). In this context, the policy envisions conversion of subsistent agriculture to commercialized and competitive system to achieve livelihood and food security through a sustained economic development. And for that, the policy has adopted three major objectives such as enhanced production and productivity, commercialized agriculture system development and conservation of natural resources and environment. The policy visualizes following devices to achieve increased production and productivity.

- intensive use of technology through agricultural research, extension and human resource development

- employment opportunities through agricultural commercialization and diversification

- land use system development and slopping land management

- intensive use of technology with development of agricultural infrastructure

- prioritized high value commodity program for remote areas

- enabled local agencies in development planning, implementation and monitoring

- development of resource/service centers (public/private) and provisions for quality supply of inputs and services

- agricultural survey surveillance system for disaster appraisal and relief

- special provisions for resource poor farmers regarding access to food, land, services, credit, irrigation facilities and other inputs

Likewise, commercialized agriculture system is foreseen to develop through pocket package program, double tract management system of government farms, organic agriculture promotion, production specialty, business oriented trainings, quality regulated supply of inputs, improved animal/plant quarantine, product standardization and regulation, market infrastructure and information system development and agribusiness promotion. In which, contract farming system and cooperative development, capital support, enhanced private and external investment and a functional state committee are instrumental to agribusiness promotion. Reduction in adverse environmental impacts of agrochemical use, promotion in production and use of organic manure, in and ex situ conservation of agrobiodiversity and related local knowledge, agroforestry development, scientific land management and conservation based agriculture system development including local participatory watershed management and stream bank protection have been major policy instruments for environment and natural resources conservation (MOAC, 2008).

Agriculture sector development and reduced climate change impact through environmental protection including physical and social infrastructure development, wider social inclusion in development and ensured easy access to social services have been among the development priorities adopted in the three years plan 2010/11-2012/13 (NPC, 2010). Enhanced agricultural productivity, soaring food prices and ensuring food security especially to remote and economically deprived communities are considered as major agriculture sector challenges. The challenges are foreseen in the plan to exacerbate by climate change and variability, lack of irrigation and technologies, animal disease outbreaks and farmers' poor access to market. Some instruments such as commercialized animal husbandry, easy access to improved breeds, reduced production cost, product quality assurance, rural infrastructure, agrobiodiversity conservation, organic farming, climate-change adaptation technologies, agriculture research and extension, contract/ cooperative farming and agriculture market development have been identified as driving elements to cope with the challenges. Agriculture land development, quality breeds/seed sources, product standardization, value addition, water harvesting and irrigation development, food access in insecure areas, crop insurance and forage/fodder development are also included as working policies. 
On such ground, the provisions in both the agriculture sector policy (though formed before the climate change concept entered into the country) and recent periodic plan are broad enough. That compared to climate change impacts visualized and priority programs recommended for adaptation (MOE, 2010a) gives an idea that many issues regarding adaptation to climate change in agriculture sector have been addressed. However, how would the policy provisions be streamlined to address possible impacts (with spatial and temporal variations) due to climate change and variability has been a major gap. Other way, the policy documents fail to elucidate how the outcomes of such implementation would reach diversity of vulnerable communities and how would the sector be contributing to capacitate the communities to adapt to the multidimensional impacts. As a result, broad based provisions in the policy documents are observed idle due to their imprecise setting and lack of appropriately identified activities for their translation into action (Fig.2). Instead of variety of provisions instrumented, design of a clear pathway to integrate some of them as required by a specific needy area would be scientific. Moreover, the policy statements also give a perception that they included multitude of interventions theoretically possible without a consideration of available resources (NPC, 2010) and priority identification. Unless impacts of climate change and variability in local settings of various components of agricultural systems in the country are well understood, outcomes of aforementioned interventions may not be fruitful as envisaged. In this regard, along with identification of urgent development interventions necessary to help peoples to adapt to possible impacts, specific priority on agricultural research to describe climate change impacts on major agricultural systems in the country would also be much relevant.

रणनीति : $\prec$ कृषिजन्य जैविक विविधताको संरक्षण संवर्द्धन र सदुपयोग गर्दे जलवायु
परिवर्तन अनुकूलन प्रविधिहरुको विकास र विस्तार गर्ने ।
कार्यनीति : $४ .9$
विश्वव्यापी जलवायु परिवर्तनलाई कृषिमा अनुकूलन गद्दे कृषि जैविक
विविधताको संरक्षण र उपयोगमा वृद्धि गरिनेछ।

Fig.2: Policy fails to establish a clear pathway in addressing climate change (NPC, 2010)

A lack of clear economic development vision and some other anomalies at policy makers' level are also observed to delude the sector and subsector policies and thereby contribute in formulation of redundant policy provisions and instruments. As discussed earlier, a clear policy vision and persuasive pathways on its achievement guide both the public and private development agencies to their proper functioning. Establishing such requires regular revisits of policy matters including instruments and their harmonization with provisions by other sector policies. Because of financial reasons and extensive efforts involved in a wider consultation and lack of coordination and easy going motive among policy makers, the sector and even subsector policies, generally formulated in isolation, are incongruous to ground situations and/or conflicting at the implementation stages. On the other hand, the state policy makers' efforts are much guided by the issues dictated by Multilateral Environmental Agreements (MEAs) and donors' interests because of financial resources and so called technical supports waived in their hands. Realizing state obligations established by MEAs is mandatory. But more important to the economies like Nepal is organizing local efforts first towards addressing state needs on account of its extreme vulnerability in the changing context. More urgent is to think about local problems and resource utilization than trading valuable time for donated supports not much productive locally. One way, fetching external support is much tedious involving a lot of formalities. Such business engages considerable local manpower and other resources in project preparation setting them away from routine job and utilization. The other way, the state has considerable resources including knowledge, techniques, experience and that endowed by nature. With well-planned interventions, limited financial resource out of that locally available can ease people through possible climatic austerities. The only required is policy makers, in view of 
mere fetching some superfluous financial supports, should not be distracted from devising local instruments to help state communities.

\section{CONCLUSIONS}

Weather variability comprising of intermittent drought, submergence, flood, intensive, hot and cold waves and irregular pattern of precipitation are considered as major parameters of changing climate having by and large adverse impacts in various aspects of agricultural system, its productivity and food security in different agro-ecological zones of the country. Understanding environmental consequences of climate change is however very complex. Its impacts on various aspects of agriculture are mere speculations of agricultural scientists built upon limited scientific justifications. Therefore, identifying climatic behavior and its consequences upon agriculture and strategic options to help agrarian communities to adapt to the changing situations is a growing challenge in agriculture sector development. Regarding which, enabling community resilience to changing situations and, for that, revisiting National Agriculture Policy 2004 and relevant subsector policies are very important. Such a reformation on policy matters should be guided to streamline agricultural research system to describe climate change impacts on agriculture and restructure agriculture sector development strategies inclusive of crucial interventions. Strategic identification of adaptation options is to some extent carried out by the thematic working group of NAPA-Project for agriculture and food security. The team has forwarded broad base adaptation response measures across major subsectors in agriculture to be incorporated in sectoral policies. Identifying climate change as a phenomenon underway to affect agricultural productivity and food security has been an urgent need of the country. In this line, the country has to center its policies and investments on key areas namely i) design and implementation of natural resource management strategies with a focus on onfarm water resources and soil management, ii) rural livelihood enabling farmers' resilience to climate change and iii) food security of its population.

\section{ACKNOWLEDGEMENT}

The authors are highly grateful to the anonymous reviewer for the excellent comments on the manuscript and acknowledge contributions by the members in the reference and thematic working groups of NAPA-project for agriculture and food security.

\section{REFERENCES}

Dahal, H. and D. R. Khanal, 2010. Food security and climate change adaptation framework: issues and challenges. Presented in Thematic Working Group (agriculture and food security) meeting, Feb 23rd, 2010, Kathmandu, Nepal. Available at: http://www.moac.gov.np/uploads/Poverty\%20and\% 20Food\%20Security\%20Updated.pdf. REetrieved on: Mar.10, 2010.

Gautam, A. K. and S. Pokhrel, 2010. Climate change effects on agricultural crops in Nepal and adaptation measures. Presented in Thematic Working Group (agriculture and food security) meeting, Feb 23rd, 2010, Kathmandu, Nepal.

Gurung G., 2008. Impacts of climate change: some field observations.

MOAC, 2010. Selected indicators of Nepalese agriculture and population. Ministry of Agriculture and Cooperatives, Kathmandu, Nepal.

MOAC, 2008. Collection of Agriculture Related Policies, Acts, Regulations and Orders (in Nepali). Ministry of Agriculture and Cooperatives, Kathmandu, Nepal.

MOE, 2010a. National adaptation program of action (NAPA) to climate change (report). Ministry of Environment, Kathmandu, Nepal.

MOE, 2010b. Climate change vulnerability mapping for Nepal. Ministry of Environment, National Adaptation Program of Action(NAPA) to Climate Change, Kathmandu, Nepal. 
MOE, 2010c. Thematic working group summary report (draft in circulation). Ministry of Environment, National Adaptation Program of Action(NAPA) to Climate Change, Kathmandu, Nepal.

Neopane, S. P., 2010. Effect of climate change on livestock, vulnerability and adaptation plans in Nepal. Presented in Presented in Thematic Working Group (agriculture and food security) meeting, Feb 23rd, 2010, Kathmandu, Nepal.

NPC, 2010. Base paper on the three-year plan 2010/11-2012/13 (in Nepali). National Planning Commission, Kathmandu, Nepal.

Pant, K. P., 2009. Effects of agriculture on climate change: a cross country study of factors affecting carbon emission. The Journal of Agriculture and Environment, 9:84-102.

Practical Action, 2009. Temporal and saptial variability of climate change over Nepal (1976 - 2005. Practical Action, Katmandu Office.

TWG, 2010a. Stocktaking report: agriculture and food security. Thematic Working Group on Agriculture and Food Security (MOAC), National Adaptation Program of Action (NAPA) to Climate Change, Kathmandu, Nepal.

TWG, 2010b. Assessing vulnerability provides foundation for identification and prioritization of adaptation measures to climate change. Thematic Working Group on Agriculture and Food Security (MOAC), National Adaptation Program of Action (NAPA) to Climate Change, Kathmandu, Nepal.

\section{ANNEX-1}

a. Prioritized agriculture sector programs/project activities recommended by the Thematic Working Group on Agriculture and Food Security

1 Increase irrigation facility and water use efficiency through promotion of shallow tube well, water collection/recycling and rainwater harvesting

2 Promotion of low cost non-conventional irrigation technology including drip/sprinkle irrigation, Thai-Jar and overhead water tank

3 Promotion of resource conservation technologies including minimum tillage, seed priming, crop mixtures, double transplanting (paddy) and widely adapted low nutrient demanding crops

4 Promotion of organic agriculture practices with special focus on bio-pesticides, organic fertilizers (manures), crop nutrition and pest management

5 Distribution of breeds, seed, seedling, sapling and fingerling adaptable to local condition

6 Promotion of community seed bank for cereals, vegetable, forage, fodder and agro-forestry species

7 Promotion of crop varieties for vulnerable areas, adaptable to climatic stresses and potential to supply high quantity food and nutrition

8 Infrastructure (such as plastic/ green house for off season vegetable) and marketing development for agro-based micro-enterprises.

9 Stockpile agricultural inputs and emergency food supplies through establishment of stores (cold and zero energy storage) and decentralized food buffer stocks

10 Organize exposure visits, vocational training and farmers' field school to enhance adaptive capacity of local institutions and target communities

11 Agriculture development policy review in terms of agricultural finance and inputs, small scale irrigation, seed banks, food storage and buffer stock and market from climate change adaptation perspectives

12 Promotion of resource efficient technologies (ensuring high income) regarding vegetables, fruits and flower production

13 Promotion of pocket area production to back up seed banks and food buffer stocks

14 Diversify food dishes of nutritionally rich cultivated and wild food crop species of local origin

15 Strengthening marketing institutions and network at strategic centers in different eco-regions

16 Improve performance of piggeries with emphasis on housing, mortality and feed

17 Promote community approach of innovative pasture and rangeland management using locally adapted fodder and forage species

18 Improve animal housing, nutrition (based on local feed, fodder and forage supply/ production) and disease and parasite management

19 Improvement of indigenous breeds of pigs, poultry, goat and sheep 
20 Studies on climate change impacts on farm animals with particular reference to reproductive cycle, heat period, infertility, diseases/parasites incidences and declining productivity

21 Promotion of poultry, dairy, goat and piggery based enterprise linking with urban markets

22 Improved collection and utilization of rain water in pasture and rangeland areas

23 Integrate eco-tourism and sport fishing in sustainable community development

24 Fish species conservation especially in the rivers used for hydropower and irrigation (improve fish migration)

25 Public-private partnership in fishery development especially fingerling supply in pond culture

26 Improve carrying capacity of natural water bodies (rivers, lakes, reservoirs and other wetlands) for sustainable community fish production and marketing.

27 Promote poly-culture and integrated pond culture with low-cost and productive technology

28 Studies on climate change impacts on fishery

29 strengthens livelihoods of ethnic minors dependant on fishing

30 Awareness raising campaign on climate change adaptation

31 Strengthen climate-change adaptation research and education

32 Establish/strengthen agro-meteostations representing various agricultural systems.

33 Establish early warning system based on science, local knowledge and practices

34 Improvement on climate resilient agricultural biodiversity and indigenous knowledge and innovations

35 Institutional development to adjust, buffer and minimize risks due to climate change

36 Protect local community rights on its natural resources and indigenous knowledge, practice, skill and innovations

37 Embankment and plantation on river bank areas

38 Sloping agricultural land management for soil conservation

39 pro-farmer land use policy and programs

40 Establishment of climate change and disaster risk management units (section or division) in NARC, DOA and DLS

b. Prioritized agriculture sector projects proposed by the Thematic Working Group on Agriculture and Food Security

1 On farm soil and water conservation in support of communities vulnerable to climate change impacts

2 Enabling climate vulnerable communities by improvement in local access to extension services

3 Strengthening highland-lowland linkages to improve community access to material goods and non-material services

4 Linking dairy and meat production to markets for enabling vulnerable communities fight against climate change impacts. 